\title{
Human papilloma virus E1-specific T cell immune response is associated with the prognosis of cervical cancer patients with squamous cell carcinoma
}

Miaomiao Ma ${ }^{1}$, Yaning Feng ${ }^{2}$, Peiwen Fan ${ }^{2}$, Xuan Yao ${ }^{3}$, Yanchun Peng ${ }^{3}$, Tao Dong ${ }^{3,4^{*}}$ and Ruozheng Wang ${ }^{1,2^{*}}$

\begin{abstract}
Background: Cervical cancer is attributable to human papilloma virus (HPV) infection in the majority cases. E1, an HPV derived-protein, plays an important role in the initiation and development of cervical cancer. Our study aims to investigate the HPV E1-specific T cell response in patients with cervical squamous cell carcinoma (CSCC).

Methods: A total of 66 CSCC patients with FIGO stage IIB-IIIB and 60 healthy controls were enrolled. Enzyme-Linked ImmunoSpot (ELISPOT) assays was used to measure the HPV E1-specific T cell response in the peripheral blood of these patients before treatment. The patients were treated with chemotherapy and/or radiotherapy and followed up clinically for three years. The relationship between the T cell response, various clinical characteristics and the prognosis were studied with univariate analysis, multivariate analysis and survival curve analysis.
\end{abstract}

Results: The frequency of HPV E1-specific T cell response in peripheral blood of cervical cancer patients was 59. 09\%, with mean response intensity 24.56 SFC $/ 10^{6}$ PBMCs. The frequency and intensity of HPV E1-specific T cell response in patients were higher than healthy controls $(p<0.001 ; p=0.009)$. The intensity of HPV E1-specific T cell responses were higher in the stage IIB patients and patients with no pelvic lymph node metastasis $(p=0.038$; $p=0.044)$. Univariate analysis showed that HPV E1 specific T cell response was associated with progression-free survival (PFS) and overall survival (OS) (PFS: $p=0.021$; OS: $p=0.004$ ). Multivariate analysis showed that HPV E1specific $T$ cell response was an independent prognostic factor influencing PFS and OS among all the factors included in our study (PFS: $H R=7.252,95 \% C l=1.690-31.126, p=0.008$; OS: $H R=7.499,95 \% C l=1.661-33.856, p=0$. 009). The survival curves showed that the rate of PFS and OS in patients with HPV E1 specific T cell response was significantly higher than those who did not response.

Conclusions: Our study demonstrated that the level of HPV E1-specific T cell response was correlated with the survival of advanced patients with CSCC. Patients who displayed no HPV E1-specific T cell response were more likely to be those with poor prognosis.

Keywords: Human papillomavirus 16, Cervical squamous cell carcinoma, Enzyme-linked immunoassay, T cell immune response, PBMC

\footnotetext{
*Correspondence: tao.dong@imm.ox.ac.uk; wrz8526@vip.163.com

Miaomiao Ma and Yaning Feng are co-first authors.

${ }^{3} \mathrm{MRC}$ Human Immunology Unit, The Weatherall Institute of Molecular

Medicine, Oxford, UK

${ }^{1}$ Department of Radiation Oncology, The Affiliated Tumor Hospital of

Xinjiang Medical University, Ürümqi, China

Full list of author information is available at the end of the article
}

(c) The Author(s). 2018 Open Access This article is distributed under the terms of the Creative Commons Attribution 4.0 International License (http://creativecommons.org/licenses/by/4.0/), which permits unrestricted use, distribution, and reproduction in any medium, provided you give appropriate credit to the original author(s) and the source, provide a link to the Creative Commons license, and indicate if changes were made. The Creative Commons Public Domain Dedication waiver (http://creativecommons.org/publicdomain/zero/1.0/) applies to the data made available in this article, unless otherwise stated. 


\section{Background}

Cervical cancer $(\mathrm{CC})$ is one of the most frequent malignant tumors among women worldwide. The incidence ranked as the second among cancers diagnosed in women [1]. It was estimated that squamous cell carcinoma (SCC) accounts for about $90 \%$ of all CCs in Xinjiang, a province located in western China [2-4], while the advanced CCs accounts for more than $60 \%$. Although radiotherapy and chemotherapy are considered to be the most effective strategies, the long-term survival of patients with advanced $\mathrm{CC}$ still remains to be improved [5]. Therefore, it is imperative to develop novel therapies to benefit more patients.

Persistent and chronic infection of high-risk types of human papillomavirus (HR-HPV), especially type 16, has been confirmed as the principal risk factor for the initiation and development of SCC [6]. In order to prevent the HPV infection and the mortality caused by HPV-related CCs, vaccines against the HR-HPV have been developed [7]. However, these prophylactic vaccines rarely showed therapeutic effects to established HPV infections or the related cervical cancer. In recent years, researchers have devoted themselves to designing therapeutic HPV vaccines. Several types of therapeutic vaccines, including recombinant protein vaccines, peptide vaccines, chimeric vaccines, nucleic acid vaccines, etc. are being assessed in terms of efficacy and safety [8-10]. However, there is not yet any such therapeutic vaccine licensed [11]. One of the main objective of the therapeutic vaccine is to initiate immune response against HPV proteins expressed on malignant tumour, which can potentially destroy the tumour eventually. T cell is a critical component of anticancer immune response. It is well recognized that $\mathrm{T}$ cell recruitment and infiltration into solid tumours are related to survival of various cancers [12]. T cells can suppress tumour growth by releasing a plethora of cytokines and/or inducing tumour cell apoptosis upon stimulation of the specific antigens presented on the surface of tumour cells [13]. Therefore, $\mathrm{T}$ cell might hold the promise of immunotherapy against HPV-related CC.

Previous studies have shown that E1 protein is necessary for HPV replication. On the transcription level, E1 can bind to upstream regulatory sequence of HPV to promote the expression of HPV E6 and E7 oncogenes [14, 15]. Some scholars demonstrated that E1 participated in the early stage of carcinogenesis and can activate specific cytotoxic $\mathrm{T}$ cell responses [16]. According to previous research considered E6 and E7 proteins are targets for immunotherapy against tumors induced by HPV [17], but the immune response to HPV E1 antigen protein was not reported. Another study also showed the E1 expression can be detected at various stages of $\mathrm{CC}$ development where the level was associated with CC prognosis [18].

We employed the enzyme-linked immunospot assay (ELISPOT) to measure the level of HPV E1-specific T cell response in peripheral blood of patients with advanced $\mathrm{CC}$ and healthy control subjects. The relationship between $\mathrm{T}$ cell response and clinical characteristics as well as the survival of the patients were analyzed so as to provide evidence for the HPV-specific therapeutic vaccine development.

\section{Methods \\ Study subjects}

The study was approved by Third Affiliated Hospital of Xinjiang Medical University Ethics Committee. From February 2014 to April 2015, 66 CSCC patients admitted to Affiliated Tumor Hospital of Xinjiang Medical University were enrolled in this study. The cervical cancer was diagnosed with clinical pathology. The age median of the patients was 54 years with the range from 39 to 80 years (Table 1). They were scored no less than 70 with Karnofsky Performance Status [19]. The patients were treatment-naive before admission and had no other types of cancer, autoimmune disease or infectious diseases. They were staged according to 2009 International Union of Gynecology and Gynecology (FIGO) clinical staging criteria, of which 32 cases were stage IIB and 34 cases were stage IIIA-IIIB (Table 1). All patients were HPV16 positive when the exfoliated cervical cells were genotyped with Hybrimax HPV DNA detection method. Meanwhile, sixty healthy women from physical examination center of the same hospital without CC were recruited as controls (aged from 24 to 60 years). None of them were high risk HPV type positive when screened with the same method as the patients. Written informed consent was given from all study subjects.

\section{Ex vivo interferon- $\gamma$ ELISPOT Assay}

Ten milliliters venous blood was obtained from each patient on the second day after admission. Peripheral blood mononuleated cells (PBMCs) were isolated from the blood with Lymphoprep (STEMCELL Technologies, origin). Interferon- $\gamma$ (IFN- $\gamma$ ) ELISPOT assay was used to measure HPV E1-specific T cell responses in the freshly isolated PBMCs as mentioned previously [16, 20]. Briefly, PBMCs were stimulated with overlapping

Table 1 The HPV E1-specific T cell response in peripheral blood of healthy controls and patients with cervical squamous cell carcinoma

\begin{tabular}{lll}
\hline Factor & \multicolumn{2}{l}{ HPV E1-specific T cell response } \\
\cline { 2 - 3 } & $\begin{array}{l}\text { Frequency } \\
(\%)\end{array}$ & $\begin{array}{l}\text { Mean magnitude } \\
\left(\mathrm{SFC} / 10^{6}\right)\end{array}$ \\
\hline Healthy controls $(N=60)$ & 26.67 & 9.94 \\
Patients & 59.09 & 24.56 \\
$(N=66)$ & & -2.594 \\
$X^{2} / Z$ & 13.433 & 0.009 \\
$P$-value & 0.000 & \\
\hline
\end{tabular}


peptide pool (Sigma-Aldrich, USA) representing the whole E1 protein in PVDF plates (Millipore, Bedford, MA, USA) pre-coated with 1-DIK monoclonal antibodies (Machete, Stockholm, Sweden) at $2 \times 10^{5}$ PBMCs/well. Meanwhile, PBMCs stimulated with $20 \mu \mathrm{g} /$ $\mathrm{mL}$ phytohemagglutinin (PHA) (Murex Biotech Limited, Dartford, UK) served as positive controls while unstimulated PBMCs were negative controls. After being cultured overnight, spot-forming cells (SFCs) were counted by automated ELISPOT assay reader (AID ELISPOT reader system, Autoimmune Diagnostika GmbH, Strassberg, Germany). Antigen-specific T-cell responses were considered positive when the number of SFCs from the peptide-pulsed well was greater than three times as many as those in negative control [21]. The adjusted SFCs after subtracting the average negative values were expressed as SFC $/ 10^{6}$ PBMCs.

\section{Treatment}

All patients were treated according to the National Comprehensive Cancer Network (NCCN) guideline of CC. Among them, 38 patients received concurrent radiotherapy and chemotherapy while 28 received radiotherapy but not chemotherapy due to the intolerance. Intracavitary irradiation (high-dose rate brachytherapy with three-dimensional conformal radiation therapy) and/or extracorporeal irradiation (intensity-modulated radiation therapy or three-dimensional conformal radiation therapy) were decided according to the patient's specific condition. Patients underwent whole-pelvic external beam radiotherapy at a dose of 45-50.4 Gy together with high-dose-rate brachytherapy. The entire para-aortic lymph node was included if the patient was found to have para-aortic lymph node involvement. High-dose-rate brachytherapy was administered at median dose of 30 Gy in 6 fractions with 5 Gy each time. According to their conditions, 57.58\% (38/66) patients received DDP (cisplatin at $40 \mathrm{mg} / \mathrm{m}^{2}$ ) per week or TP (taxol $135 \mathrm{mg} / \mathrm{m}^{2}+$ cisplatin $50 \mathrm{mg} / \mathrm{m}^{2}$ ) three times during radiotherapy.

\section{Follow-up}

Post-treatment follow-up visits were scheduled at 1 month, 3 months, and then every 3 months for the first 2 years, and then every 6 months for the next 2 years. Either interview through telephone calls or re-examination in hospital were used to determine the patients' condition during the follow-up. Overall survival (OS) was defined as the time between the date of the end of treatment and the date of CC-related death or the last follow-up. Progression-free survival (PFS) referred to the time from the date when treatment ended to the date of progression of the tumor or the last day of follow-up.

\section{Statistical analysis}

All statistical analyses were performed using SPSS version 17.0 (SPSS Inc., Chicago, IL, USA). The data not fitting normal distribution was analyzed with rank sum test. The count data were analyzed by the Chi-square test. Two-tailed Fisher's exact test was conducted where Chi-square test was not applicable. OS and PFS were analyzed by the Kaplan-Meier method, the statistical significance of which was determined by log-rank test. The clinical features and the E1-specifc $\mathrm{T}$ cell response were included in the multivariate analysis based on the Cox proportional hazard model using the stepwise method. $P<0.05$ was considered statistically significant.

\section{Results}

HPV E1-specific T responses in patients with cervical squamous cell carcinoma were stronger than healthy controls

The frequency of HPV E1-specific T cell response in peripheral blood of the 60 healthy controls was $26.67 \%$ and the mean response intensity was 9.94 SFC $/ 10^{6}$ PBMCs, while that of the 66 CSCC patients was $59.09 \%$ and $24.56 \mathrm{SFC} / 10^{6}$ PBMCs, respectively (Fig. 1). The frequency and intensity of HPV E1-specific $\mathrm{T}$ response in patients were higher than healthy controls $\left(X^{2}=13.433, p<0.001 ; Z=-2.594\right.$, $p=0.009)$. There were statistically significant difference between the two groups (Table 1).

\section{HPV E1-specific T cell responses differed among patients of stage IIB and IIIB}

No significant difference was found in the response frequency when the patients were grouped with age, family history of cancer, abortion history, tumor size, histological type, pathological grade, clinical stage, levels of Squamous cell carcinoma antigen (SCC-Ag), Carcinoembryonic antigen (CEA), Tumor specific growth factor (TSGF), or pelvic lymph node metastasis (Table 2).

It was noted that the intensity of HPV E1-specific $\mathrm{T}$ cell responses in stageII group were higher than III group, the differences of which were statistically significant $(Z=-2.077, p=0.038)$. The intensity of HPV E1-specific T cell responses in no pelvic lymph node metastasis group were significantly higher than pelvic lymph node metastasis group $(Z=-2.017, p$ $=0.044$ ). However, when comparing $\mathrm{T}$ cell response intensity between patients grouped by ethnicities, age, family history of cancer, abortion history, tumor size, histological type, pathological grade, SCC-Ag level or CEA level, TSGF level, no significant difference was found (Table 3). 


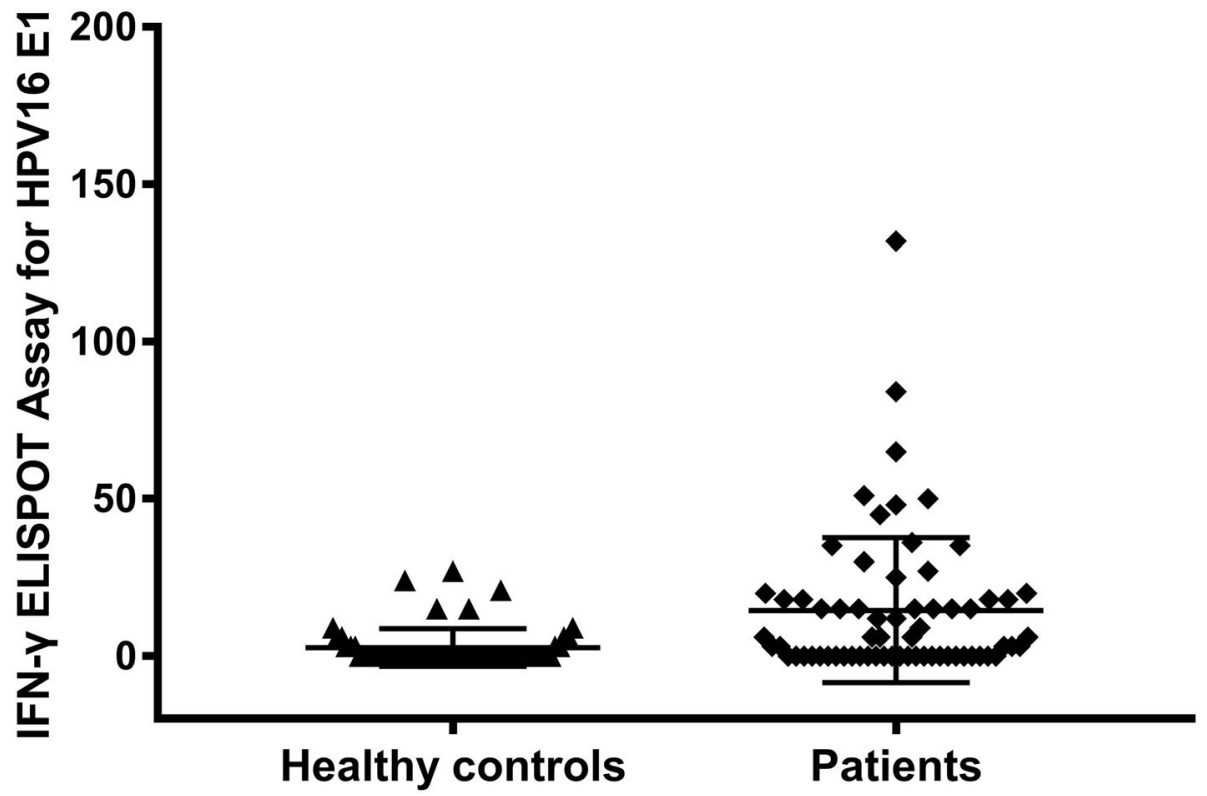

Fig. 1 The HPV E1-specific T cell responses in peripheral blood of healthy controls and patients with cervical squamous cell carcinoma by IFN-ץELISPOT Assay

\section{HPV E1-specific T cell response was related to the prognosis}

To see if E1-specifc $\mathrm{T}$ cell response was related to $\mathrm{CC}$ prognosis, the patients were followed as the protocol mentioned above for a median period of 36 months (range 4 to 48 months). The last follow-up date was May 2018. Two patients were lost and the follow-up rate ended up with $96.97 \%$. Of the 66 patients, 13 died from recurrent and metastatic disease, 1 died from uremia syndrome. The 3-year OS and PFS rates were 79.69 and $76.56 \%$, respectively. Univariate analysis showed that the HPV E1-T cell response was related to the PFS and OS of CC. Patients showing E1-specific T cell response displayed significantly improved PFS compared to the non-responders, the difference of which was significant $\left(\chi^{2}=5.307, p=0.021 ; \chi^{2}=8.078, p=0.004\right)$. Age was also found to be correlated with the PFS $\left(\chi^{2}=3.963, p=\right.$ 0.047) (Table 4).

We further analyzed the weight of various factors on the prognosis of patients with cervical cancer. Multivariate Cox regression analysis was performed to determine if survival of the advance CC patients was correlated with any clinical features or E1-specific $\mathrm{T}$ cell response. It was found that the presence of E1-specific $\mathrm{T}$ cell response was independently correlated with better PFS and OS (Hazard ratio [HR] 7.252, 95\% Confidence interval $[\mathrm{CI}] 1.690-31.126, p=0.008$ and $H R=7.499,95 \% C I$ $=1.661-33.856, p=0.009$, respectively). Besides, younger age was observed to be related to better PFS of patients $(H R=5.423,95 \% C I=1.113-26.419, p=0.036)$ (Table 5) and no pelvic lymph node metastasis group had better
PFS of patients $(H R=5.035,95 \% C I=1.140-22.231, p=$ 0.033) (Table 5).

Kaplan-Meier survival curve analysis revealed the association of HPV E1-specific T cell response with survival

Kaplan-Meier analysis was used to estimate the survival difference between E1-specific responders and non-responders. The survival curves demonstrated that presence of E1-specific $\mathrm{T}$ cell response was associated with significantly higher PFS and OS (Log-rank value (Mantel-Cox) $=5.307, p=0.021$; Log-rank value (Mantel-Cox) $=8.153, p=0.004$, respectively) (Fig. 2). In other words, patients displaying HPV E1-specific T cell response had significantly improved PFS and OS.

\section{Discussion}

In recent years, with accumulating knowledge of the relationship between HPV and CC [22, 23], researchers have invested a great amount of effort to develop immunotherapies that can effectively treat CC. It is believed that $\mathrm{T}$ cells, an important part of adaptive immune response, play major roles in suppressing and eliminating HPV-infected cells [24-26]. Therefore, exploiting the curative potential of $\mathrm{T}$ cells can benefit CC patients who are not well treated with conventional methods such as chemotherapy and radiotherapy.

Our previous study reported that the frequency of HPV E1-specific T response was higher in patients with head and neck squamous cell carcinoma than in healthy controls [27]. Since HPV contributes to the development 
Table 2 The relationship between response frequency of HPV E1-specific T cell response in peripheral blood and clinical features in patients with cervical squamous cell carcinoma

\begin{tabular}{|c|c|c|c|c|c|}
\hline Factor & & $N$ & $\begin{array}{l}\text { Frequency } \\
(\%)\end{array}$ & $x^{2}$ & $P$-value \\
\hline \multirow{2}{*}{$\begin{array}{l}\text { Age } \\
\text { (year) }\end{array}$} & $\leq 54$ & 32 & 53.13 & 0.915 & 0.339 \\
\hline & $>54$ & 34 & 64.71 & & \\
\hline \multirow{2}{*}{$\begin{array}{l}\text { Family history } \\
\text { of cancer }\end{array}$} & No & 59 & 57.63 & 0.678 & 0.767 \\
\hline & Yes & 7 & 71.43 & & \\
\hline \multirow{2}{*}{$\begin{array}{l}\text { History of } \\
\text { miscarriage }\end{array}$} & No & 30 & 56.67 & 0.134 & 0.715 \\
\hline & Yes & 36 & 61.11 & & \\
\hline \multirow{2}{*}{$\begin{array}{l}\text { Tumor size } \\
(\mathrm{cm})\end{array}$} & $\leq 5$ & 43 & 58.14 & 0.046 & 0.830 \\
\hline & $>5$ & 23 & 60.87 & & \\
\hline \multirow[t]{4}{*}{ Tumor type } & Cauliflower & 25 & 52.00 & 1.868 & 0.60 \\
\hline & Nodular & 29 & 58.62 & & \\
\hline & Hollow & 7 & 71.43 & & \\
\hline & Others & 5 & 80.00 & & \\
\hline \multirow{4}{*}{$\begin{array}{l}\text { Histologic } \\
\text { grade }\end{array}$} & Well & 2 & 0 & 4.465 & 0.215 \\
\hline & Moderate & 45 & 64.44 & & \\
\hline & Poor & 13 & 53.85 & & \\
\hline & Papillary & 6 & 50.00 & & \\
\hline \multirow[t]{2}{*}{ FIGO stage } & $\| \mathrm{B}$ & 34 & 59.38 & 0.002 & 0.964 \\
\hline & $\||| A-\||| B$ & 32 & 58.82 & & \\
\hline \multirow[t]{2}{*}{ SCC-Ag } & Normal & 12 & 75.00 & 1.536 & 0.215 \\
\hline & Anormal & 54 & 55.56 & & \\
\hline \multirow[t]{2}{*}{ CEA } & Normal & 42 & 64.29 & 1.289 & 0.256 \\
\hline & Anormal & 24 & 50.00 & & \\
\hline \multirow[t]{2}{*}{ TSGF } & Normal & 46 & 54.35 & 1.413 & 0.235 \\
\hline & Anormal & 20 & 70.00 & & \\
\hline \multirow{2}{*}{$\begin{array}{l}\text { Pelvic lymph } \\
\text { nodes }\end{array}$} & No & 37 & 64.86 & 1.161 & 0.281 \\
\hline & Yes & 29 & 51.72 & & \\
\hline
\end{tabular}

$N$ number of patients, FIGO International Federation of Gynecology and Obstetrics, SCC-Ag Squamous cell carcinoma antigen, CEA carcinoembryonic antigen, TSGF Tumor specific growth factor

of $\mathrm{CC}$, we explored whether E1-specific immune response existed in $\mathrm{CC}$ patients. In this study, we found that CC patients displayed stronger E1-specific $\mathrm{T}$ cell response than healthy controls. The HPV16 infection of study subjects among different groups were an important reason for the inconsistency.

HPV E1-specific $\mathrm{T}$ cell responses were observed in some healthy controls. One explanation was that these subjects were previously infected by HPV16 but later the virus was cleared by the immune system in a relatively short time [28]. The $\mathrm{T}$ cell response was elicited by the memory $\mathrm{T}$ cells due to the infection. It is also noteworthy that not all patients had E1-specific $\mathrm{T}$ cell response. An important factor that may affect the $\mathrm{T}$ cell response is HPV DNA physical status. It was reported that in advanced CC, HPV DNA tends to integrate into
Table 3 The relationship between response intensity of HPV E1specific $T$ cell response in peripheral blood and the clinical features in patients with cervical squamous cell carcinoma

\begin{tabular}{|c|c|c|c|c|c|}
\hline Factor & & $N$ & $\begin{array}{l}\text { Mean } \\
\text { magnitude } \\
\left(\mathrm{SFC} / 10^{6}\right)\end{array}$ & Z & $P$-value \\
\hline \multirow{2}{*}{$\begin{array}{l}\text { Age } \\
\text { (year) }\end{array}$} & $\leq 54$ & 32 & 20.06 & \multirow[t]{2}{*}{-0.598} & \multirow[t]{2}{*}{0.550} \\
\hline & $>54$ & 34 & 28.05 & & \\
\hline \multirow{2}{*}{$\begin{array}{l}\text { Family history } \\
\text { of cancer }\end{array}$} & No & 59 & 24.74 & \multirow[t]{2}{*}{-0.570} & \multirow[t]{2}{*}{0.568} \\
\hline & Yes & 7 & 23.4 & & \\
\hline \multirow{2}{*}{$\begin{array}{l}\text { History of } \\
\text { miscarriage }\end{array}$} & No & 30 & 24.88 & \multirow[t]{2}{*}{-0.570} & \multirow[t]{2}{*}{0.569} \\
\hline & Yes & 36 & 24.32 & & \\
\hline \multirow{2}{*}{$\begin{array}{l}\text { Tumor size } \\
(\mathrm{cm})\end{array}$} & $\leq 5$ & 43 & 23.4 & \multirow[t]{2}{*}{-0.662} & \multirow[t]{2}{*}{0.508} \\
\hline & $>5$ & 23 & 26.64 & & \\
\hline \multirow[t]{4}{*}{ Tumor type } & Cauliflower & 25 & 24.77 & \multirow[t]{4}{*}{-0.115} & \multirow[t]{4}{*}{0.909} \\
\hline & Nodular & 29 & 24.65 & & \\
\hline & Hollow & 7 & 24.6 & & \\
\hline & Others & 5 & 23.5 & & \\
\hline \multirow{4}{*}{$\begin{array}{l}\text { Histologic } \\
\text { grade }\end{array}$} & Well & 2 & 0 & \multirow[t]{4}{*}{-1.826} & \multirow[t]{4}{*}{0.068} \\
\hline & Moderate & 45 & 21.31 & & \\
\hline & Poor & 13 & 39.28 & & \\
\hline & Papillary & 6 & 21.67 & & \\
\hline \multirow[t]{2}{*}{ FIGO stage } & $\| B$ & 34 & 27.45 & \multirow[t]{2}{*}{-2.077} & \multirow[t]{2}{*}{0.038} \\
\hline & $\||| A-\| B$ & 32 & 21.53 & & \\
\hline \multirow[t]{2}{*}{ SCC-Ag } & Normal & 12 & 23 & \multirow[t]{2}{*}{-0.419} & \multirow[t]{2}{*}{0.675} \\
\hline & Anormal & 54 & 25.03 & & \\
\hline \multirow[t]{2}{*}{ CEA } & Normal & 42 & 22.56 & \multirow[t]{2}{*}{-1.239} & \multirow[t]{2}{*}{0.215} \\
\hline & Anormal & 24 & 29.08 & & \\
\hline \multirow[t]{2}{*}{ TSGF } & Normal & 46 & 30.72 & \multirow[t]{2}{*}{-1.958} & \multirow[t]{2}{*}{0.050} \\
\hline & Anormal & 20 & 13.57 & & \\
\hline \multirow{2}{*}{$\begin{array}{l}\text { Pelvic } \\
\text { lymph nodes }\end{array}$} & No & 37 & 25.58 & \multirow[t]{2}{*}{-2.017} & \multirow[t]{2}{*}{0.044} \\
\hline & Yes & 29 & 22.93 & & \\
\hline
\end{tabular}

$N$ number of patients, Mean magnitude of T cell response of the population, FIGO International Federation of Gynecology and Obstetrics, SCC-Ag Squamous cell carcinoma antigen, CEA carcinoembryonic antigen, TSGF Tumor specific growth factor

host DNA, often resulting in disruption of HPV16 E1 open reading frames thus absence of E1 protein expression [29]. Therefore, E1-specific T cell response cannot be observed in every patient.

We also studied the relationship between HPV E1-specific $\mathrm{T}$ cell response in $\mathrm{CC}$ patients and their prognosis during a four-year follow up. The correlation between positive E1-specific $\mathrm{T}$ cell response and better PFS and OS was found when using univariate analysis (Table 3). Mulitvariate analysis revealed that both the E1-specific $\mathrm{T}$ cell response and age influenced the PFS and OS following chemoradiotherapy in advanced CC patients (Table 4). It was also worth to mention that generally those whose $\mathrm{T}$ cell responded to $\mathrm{E} 1$ stimulation 
Table 4 Log-rank analysis of prognostic factors in cervical squamous cell carcinoma patients

\begin{tabular}{|c|c|c|c|c|c|c|c|}
\hline \multirow[t]{2}{*}{ Factor } & & \multicolumn{3}{|l|}{ PFS } & \multicolumn{3}{|l|}{ OS } \\
\hline & & 3-year (\%) & $x^{2}$ & $\overline{P \text {-value }}$ & 3-year (\%) & $x^{2}$ & $P$-value \\
\hline \multirow{2}{*}{$\begin{array}{l}\text { Age } \\
\text { (year) }\end{array}$} & $\leq 54$ & 84.91 & 3.963 & 0.047 & 88.66 & 2.392 & 0.122 \\
\hline & $>54$ & 64.52 & & & 67.74 & & \\
\hline \multirow[t]{2}{*}{ Family history of cancer } & No & 71.70 & 1.884 & 0.170 & 75.47 & 1.618 & 0.203 \\
\hline & Yes & 100.00 & & & 100.00 & & \\
\hline \multirow[t]{2}{*}{ History of miscarriage } & No & 66.67 & 2.299 & 0.129 & 74.07 & 0.945 & 0.331 \\
\hline & Yes & 80.33 & & & 80.33 & & \\
\hline \multirow{2}{*}{$\begin{array}{l}\text { Tumor size } \\
(\mathrm{cm})\end{array}$} & $\leq 5$ & 73.68 & 0.027 & 0.870 & 78.95 & 0.085 & 0.771 \\
\hline & $>5$ & 74.36 & & & 74.36 & & \\
\hline \multirow[t]{4}{*}{ Tumor type } & Cauliflower & 76.74 & 0.214 & 0.644 & 76.74 & 0.033 & 0.857 \\
\hline & Nodular & 72.00 & & & 76.00 & & \\
\hline & Hollow & 57.14 & & & 71.43 & & \\
\hline & Others & 100.00 & & & 100.00 & & \\
\hline \multirow[t]{4}{*}{ Histologic grade } & Well & 50.00 & 0.239 & 0.625 & 50.00 & 0.066 & 0.797 \\
\hline & Moderate & 75.31 & & & 80.25 & & \\
\hline & Poor & 66.67 & & & 66.67 & & \\
\hline & Papillary & 83.33 & & & 83.33 & & \\
\hline \multirow[t]{2}{*}{ FIGO stage } & $\| \mathrm{B}$ & 82.46 & 1.271 & 0.260 & 82.46 & 1.166 & 0.280 \\
\hline & $\|A-\| B$ & 72.41 & & & 65.52 & & \\
\hline \multirow[t]{2}{*}{ SCC-Ag } & Normal & 90.00 & 1.854 & 0.173 & 90.00 & 1.367 & 0.242 \\
\hline & Anormal & 70.53 & & & 74.74 & & \\
\hline \multirow[t]{2}{*}{ CEA } & Normal & 80.56 & 1.951 & 0.163 & 86.00 & 3.238 & 0.072 \\
\hline & Anormal & 62.79 & & & 62.79 & & \\
\hline \multirow[t]{2}{*}{ TSGF } & Normal & 72.84 & 0.191 & 0.662 & 77.78 & 0.003 & 0.960 \\
\hline & Anormal & 76.47 & & & 76.47 & & \\
\hline \multirow[t]{2}{*}{ Pelvic lymph nodes } & No & 79.59 & 1.698 & 0.193 & 79.59 & 0.571 & 0.450 \\
\hline & Yes & 69.70 & & & 75.76 & & \\
\hline \multirow[t]{2}{*}{ HPV E1 } & Positive & 85.29 & 5.307 & 0.021 & 91.18 & 8.078 & 0.004 \\
\hline & Negative & 57.45 & & & 57.45 & & \\
\hline \multirow[t]{2}{*}{ Treatment } & Radiotherapy + chemotherapy & 78.13 & 1.073 & 0.300 & 81.25 & 0.265 & 0.607 \\
\hline & Radiotherapy & 68.63 & & & 72.55 & & \\
\hline
\end{tabular}

FIGO International Federation of Gynecology and Obstetrics, SCC-Ag Squamous cell carcinoma antigen, CEA carcinoembryonic antigen, TSGF Tumor specific growth factor, HPV Human papillomavirus

had better survival, suggesting the anticancer function of the $\mathrm{T}$ cell in cervical cancer.

The conventional treatment modality like radiotherapy and chemotherapy are currently the most commonly used to treat advanced CCs. However, the long-term survival of advanced CC is still low $[5,30]$. To improve the survival, novel immunotherapies are being developed. $\mathrm{T}$ cells are versatile in suppressing cancer development. Upon stimulation with the antigen, $\mathrm{T}$ cell can either disrupt cancer cell function by releasing cytokines or directly kill the cancer cells by inducing apoptosis. Therefore, it is worthwhile to develop $\mathrm{T}$ cell-based immunotherapies to fight against advanced CCs. Vaccines have been developed against various
HPV16-derived epitopes [31]. Rahma et al. [32] reported the immunogenicity of two epitopes from HPV16 E6 and E7 in advanced CC patients, with response rates $63 \%(10 / 16)$ and $58 \%$ (7/12), respectively. The study proved the feasibility of therapeutic vaccines against HPV derived-epitopes. But the problem remained that E6 or E7 cannot initiated immune response in every patient from the above report. Thus, in our study, we looked into the possibility to target HPV E1 to broaden the application to CC patients. According to our result, $\mathrm{T}$ cell response against $\mathrm{E} 1$ protein can be observed in a subgroup of advanced CC patients. Moreover, the stronger $\mathrm{T}$ cell response was related to better prognosis. It can be seen that those patients can benefit from the E1-specific $\mathrm{T}$ 
Table 5 Cox regression analyses of progression-free survival in cervical squamous cell carcinoma patients

\begin{tabular}{|c|c|c|c|c|}
\hline \multirow[t]{2}{*}{ Factor } & \multicolumn{2}{|l|}{ PFS } & \multicolumn{2}{|l|}{ OS } \\
\hline & $\begin{array}{l}\mathrm{HR} \\
(95 \% \mathrm{Cl})\end{array}$ & $P$-value & $\begin{array}{l}\mathrm{HR} \\
(95 \% \mathrm{Cl})\end{array}$ & $P$-value \\
\hline$\overline{\text { Age }}$ & $\begin{array}{l}5.423 \\
(1.113-26.419)\end{array}$ & 0.036 & $\begin{array}{l}4.265 \\
(0.901-20.194)\end{array}$ & 0.067 \\
\hline Family history of cancer & - & - & - & - \\
\hline History of miscarriage & $\begin{array}{l}0.521 \\
(0.150-1.809)\end{array}$ & 0.304 & $\begin{array}{l}0.735 \\
(0.208-2.600)\end{array}$ & 0.634 \\
\hline Tumor size & $\begin{array}{l}1.629 \\
(0.443-5.598)\end{array}$ & 0.463 & $\begin{array}{l}2.310 \\
(0.571-9.345)\end{array}$ & 0.240 \\
\hline Tumor type & $\begin{array}{l}0.947 \\
(0.400-2.239)\end{array}$ & 0.901 & $\begin{array}{l}0.594 \\
(0.194-1.820)\end{array}$ & 0.362 \\
\hline Histologic grade & $\begin{array}{l}0.922 \\
(0.374-2.271)\end{array}$ & 0.860 & $\begin{array}{l}0.772 \\
(0.291-2.045)\end{array}$ & 0.602 \\
\hline FIGO stage & $\begin{array}{l}1.031 \\
(0.221-4.804)\end{array}$ & 0.969 & $\begin{array}{l}0.934 \\
(0.196-4.450)\end{array}$ & 0.931 \\
\hline SCC-Ag & $\begin{array}{l}0.720 \\
(0.067-7.774)\end{array}$ & 0.787 & $\begin{array}{l}0.931 \\
(0.086-10.035)\end{array}$ & 0.953 \\
\hline CEA & $\begin{array}{l}0.766 \\
(0.194-3.015)\end{array}$ & 0.702 & $\begin{array}{l}1.902 \\
(0.342-10.581)\end{array}$ & 0.463 \\
\hline TSGF & $\begin{array}{l}0.381 \\
(0.096-1.515)\end{array}$ & 0.171 & $\begin{array}{l}0.657 \\
(0.154-2.808)\end{array}$ & 0.571 \\
\hline Pelvic lymph nodes & $\begin{array}{l}5.035 \\
(1.140-22.231)\end{array}$ & 0.033 & $\begin{array}{l}2.844 \\
(0.571-14.166)\end{array}$ & 0.202 \\
\hline HPV E1-specific T cell response & $\begin{array}{l}7.252 \\
(1.690-31.126)\end{array}$ & 0.008 & $\begin{array}{l}7.499 \\
(1.661-33.856)\end{array}$ & 0.009 \\
\hline Treatment & $\begin{array}{l}1.595 \\
(0.532-4.784)\end{array}$ & 0.405 & $\begin{array}{l}0.118 \\
(0.347-3.603)\end{array}$ & 0.851 \\
\hline
\end{tabular}

FIGO International Federation of Gynecology and Obstetrics, SCC-Ag Squamous cell carcinoma antigen, CEA carcinoembryonic antigen, TSGF Tumor specific growth factor, HPV Human papillomavirus

cell response, which served as an evidence to develop immunotherapy.

However, there are several limitations to this study. Firstly, the $\mathrm{T}$ cell response to E1 was only measured in advanced CC patients whereas it remained to be determined how $\mathrm{T}$ cell respond in patients staged other than II or III. Secondly, since PBMCs instead of isolated T cell subsets were used in ELISPOT assay, it was not possible to tell which $\mathrm{T}$ cell subsets were responsible for the E1-specific response since both $\mathrm{CD} 4+$ and $\mathrm{CD} 8+\mathrm{T}$ cell can secret IFN- $\gamma$. Besides, it would be informative if HPV16 negative patients were included in our study.
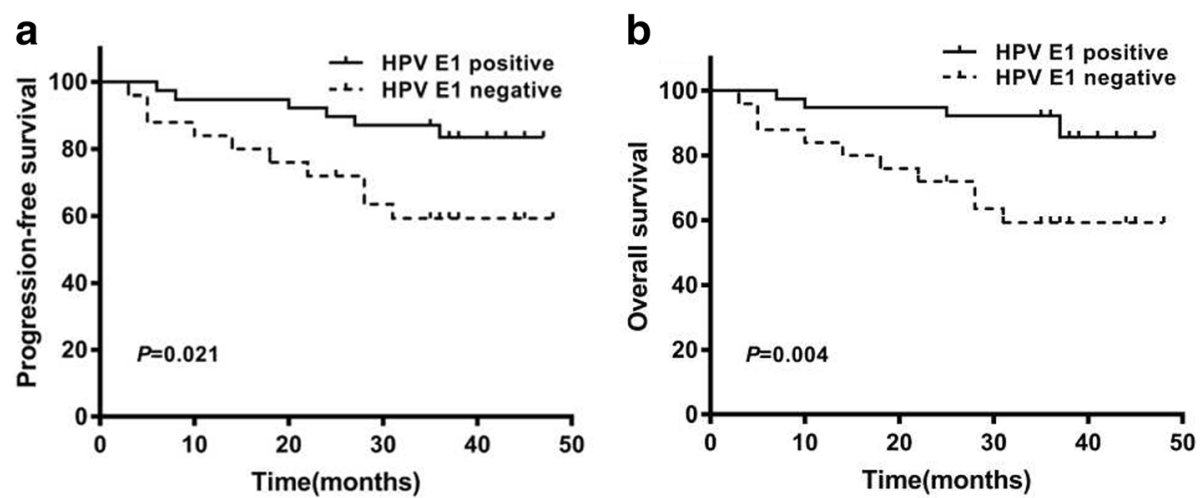

Fig. 2 Survival difference between cervical squamous cell carcinoma in patients with or without HPV E1-specific T cells response. a Kaplan-Meier plot for progression-free survival (PFS) analysis of advanced CC patients with or without HPV E1-specific T cell response. b Kaplan-Meier plot for overall survival (OS) analysis of advanced CC patients with or without HPV E1-specific T cell response 
However, HPV16-negative patients were rare and often they were diagnosed with cervical adenocarcinoma, which display different clinical features to CSCC.

\section{Conclusions}

In conclusion, the characteristics of HPV E1-specific T cell immune response in peripheral blood of patients with CC was significantly related to the clinical characteristics and prognosis. It is worthwhile to investigate the potentiality of E1 as an immunotherapy target in the future so as to provide evidence for the HPV-specific therapeutic vaccine development.

\section{Abbreviations}

CEA: Carcinoembryonic antigen; Cl: Confidence interval; CSCC: Cervical squamous cell carcinoma; FIGO: Federation of Gynecology; HR: Hazard ratio; HR-HPV: High risk human papillomavirus; OS: Overall survival; PFS: Progression-free survival; SCC-Ag: Squamous cell carcinoma associated antigen; TSGF: Tumor specific growth factor

\section{Acknowledgement}

We thank all the patients and healthy women for participating in this study and donating their blood samples.

\section{Funding}

This work was supported by the regional joint fund of the National Natural Science Foundation of China (Grant number U1603282).

\section{Availability of data and materials}

The datasets used and/or analyzed during the current study are available from the corresponding author on reasonable request.

\section{Authors' contributions}

Conception and design: TD, RW; Administrative support: TD, RW; Provision of study materials or patients: YP, XY, MM; Collection and assembly of data: MM, YF, PF; Data analysis and interpretation: MM, YF, PF, XY; Manuscript writing: All authors; Final approval of manuscript: All authors.

\section{Ethics approval and consent to participate}

All patients and healthy women provided written informed consent before entering the study. This study was approved by the Institutional Ethics Committee of Affiliated Tumor Hospital of Xinjiang Medical University. This study was carried out according to the principles recommended in the Declaration of Helsinki 1964 and all subsequent revisions.

\section{Consent for publication}

Not applicable.

\section{Competing interests}

The authors declare that they have no competing interests.

\section{Publisher's Note}

Springer Nature remains neutral with regard to jurisdictional claims in published maps and institutional affiliations.

\footnotetext{
Author details

'Department of Radiation Oncology, The Affiliated Tumor Hospital of Xinjiang Medical University, Ürümqi, China. ${ }^{2}$ Key Laboratory of Cancer Immunotherapy and Radiotherapy, Chinese Academy of Medical Sciences, Ürümqi, China. ${ }^{3} \mathrm{MRC}$ Human Immunology Unit, The Weatherall Institute of Molecular Medicine, Oxford, UK. ${ }^{4}$ Nuffeld Department of Medicine, CAMS Oxford Center for Translational Immunology, Chinese Academy of Medical Science Oxford Institute, Oxford University, Oxford, UK.
}

Received: 7 August 2018 Accepted: 26 October 2018

Published online: 16 November 2018

\section{References}

1. Torre LA, Islami F, Siegel RL, Ward EM, Jemal A. Global Cancer in Women: Burden and Trends. Cancer Epidemiol Biomark Prev. 2017;26(4):444-57.

2. Chen W, Zheng R, Zhang S, Zeng H, Xia C, Zuo T, et al. Cancer incidence and mortality in China, 2013. Cancer Lett. 2017:401:63-71.

3. Li K, Yin R, Wang D, Li Q. Human papillomavirus subtypes distribution among 2309 cervical cancer patients in West China. Oncotarget. 2017; 8(17):28502-9.

4. Wang B, He M, Chao A, Engelgau MM, Saraiya $M$, Wang $L$, et al. Cervical Cancer Screening Among Adult Women in China, 2010. Oncologist. 2015;20(6):627-34

5. McLachlan J, Boussios S, Okines A, Glaessgen D, Bodlar S, Kalaitzaki R, et al. The Impact of Systemic Therapy Beyond First-line Treatment for Advanced Cervical Cancer. Clin Oncol (R Coll Radiol). 2017;29(3):153-60.

6. Bosch FX, Robles C, Díaz M, Arbyn M, Baussano I, Clavel C, et al. HPVFASTER: broadening the scope for prevention of HPV-related cancer. Nat Rev Clin Oncol. 2016;13(2):119-32.

7. Beachler DC, Kreimer AR, Schiffman M, Herrero R, Wacholder S, Rodriguez AC, et al. Multisite HPV16/18 Vaccine Efficacy Against Cervical, Anal, and Oral HPV Infection. J Natl Cancer Inst. 2016;(1):108.

8. Ilyinskii PO, Kovalev Gl, O'Neil CP, Roy CJ, Michaud AM, Drefs NM, et al. Synthetic vaccine particles for durable cytolytic T lymphocyte responses and anti-tumor immunotherapy. PLoS One. 2018;13(6):e0197694.

9. Mukherjee S, Hussaini R, White R, Atwi D, Fried A, Sampat S, et al. TriCurin, a synergistic formulation of curcumin, resveratrol, and epicatechin gallate, repolarizes tumor-associated macrophages and triggers an immune response to cause suppression of HPV+ tumors. Cancer Immunol Immunother. 2018:67(5):761-74.

10. Cordeiro MN, De Lima RCP, Paolini F, Melo ARDS, Campos ADF, Venuti A, et al. Current research into novel therapeutic vaccines against cervical cancer. Expert Rev Anticancer Ther. 2018;18(4):365-76.

11. Yang $A$, Jeang J, Cheng $\mathrm{K}$, Cheng $\mathrm{T}$, Yang B, Wu TC, et al. Current state in the development of candidate therapeutic HPV vaccines. Expert Rev Vaccines. 2016:15(8):989-1007.

12. Gajewski TF. The Next Hurdle in Cancer Immunotherapy: Overcoming the Non-TCell-Inflamed Tumor Microenvironment. Semin Oncol. 2015;42(4):663-71.

13. Çuburu N, Khan S, Thompson CD, Kim R, Vellinga J, Zahn R, et al. Adenovirus vector-based prime-boost vaccination via heterologous routes induces cervicovaginal CD8 T cell responses against HPV16 oncoproteins. Int J Cancer. 2018;142(7):1467-79.

14. Reinson T, Henno L, Toots M, Ustav M, Ustav M. The Cell Cycle Timing of Human Papillomavirus DNA Replication. PLoS One. 2015;10(7):e0131675.

15. Kantang W, Chunsrivirot S, Muangsin N, Poovorawan Y, Krusong K. Design of peptides as inhibitors of human papillomavirus 16 transcriptional regulator E1-E2. Chem Biol Drug Des. 2016;88(4):475-84.

16. Ragonnaud E, Pedersen AG, Holst PJ. Breadth of T Cell Responses After Immunization with Adenovirus Vectors Encoding Ancestral Antigens or Polyvalent Papillomavirus Antigens. Scand J Immunol. 2017:85(3):182-90.

17. Grabowska AK, Kaufmann AM, Riemer AB. Identification of promiscuous HPV16-derived T helper cell epitopes for therapeutic HPV vaccine design. Int J Cancer. 2015;136(1):212-24.

18. Baedyananda F, Chaiwongkot A, Bhattarakosol P. Elevated HPV16 E1 Expression Is Associated with Cervical Cancer Progression. Intervirology. 2017:60(5):171-80.

19. Tandon P, Reddy KR, O'Leary JG, Garcia-Tsao G, Abraldes JG, Wong F, et al A Karnofsky performance status-based score predicts death after hospital discharge in patients with cirrhosis. Hepatology. 2017;65(1):217-24.

20. Zhang H, Han X, Zhao B, An M, Wang Z, Jiang F, et al. Multilayered HIV-1 gag-specific T-cell responses contribute to slow progression in $\mathrm{HLA}-\mathrm{A}^{*} 30$ $B^{*} 13-C^{*} 06$-positive patients. AIDS. 2015;29(9):993-1002.

21. Yuan K, Wu X, Zhang Q, Zhong Z, Chen J. Enzyme-linked immunospot assay response to recombinant CFP-10/ESAT-6 fusion protein among patients with spinal tuberculosis: implications for diagnosis and monitoring of surgical therapy. Int J Infect Dis. 2013;17(9):e733-8.

22. Li P, Tan Y, Zhu LX, Zhou LN, Zeng P, Liu Q, et al. Prognostic value of HPV DNA status in cervical cancer before treatment: a systematic review and meta-analysis. Oncotarget. 2017;8(39):66352-9. 
23. Benard VB, Castle PE, Jenison SA, Hunt WC, Kim JJ, Cuzick J, et al. Population-Based Incidence Rates of Cervical Intraepithelial Neoplasia in the Human Papillomavirus Vaccine Era. JAMA Oncol. 2017;3(6):833-7.

24. Mittal S, Banks L. Molecular mechanisms underlying human papillomavirus E6 and E7 oncoprotein-induced cell transformation. Mutat Res Rev Mutat Res. 2017;772:23-35.

25. Di Bonito P, Chiozzini C, Arenaccio C, Anticoli S, Manfredi F, Olivetta E, et al. Antitumor HPV E7-specific CTL activity elicited by in vivo engineered exosomes produced through DNA inoculation. Int I Nanomedicine. 2017;12:4579-91.

26. Mizuuchi M, Hirohashi Y, Torigoe T, Kuroda T, Yasuda K, Shimizu Y, et al. Novel oligomannose liposome-DNA complex DNA vaccination efficiently evokes anti-HPV E6 and E7 CTL responses. Exp Mol Pathol. 2012;92(1):185-90.

27. Huang L, Fan PW, Liu K, Wang RZ. Analysis of human papillomavirus specific cytotoxic lymphocyte immune response in head and neck carcinoma patients. [Article in Chinese]. Journal of XinJiang Medical University. 2017:40(7):857-61.

28. Tommasino M. The human papillomavirus family and its role in carcinogenesis. Semin Cancer Biol. 2014;26:13-21.

29. Amaro-Filho SM, Pereira Chaves CB, Felix SP, Basto DL, de Almeida LM, Moreira MAM. HPV DNA methylation at the early promoter and E1/E2 integrity: A comparison between HPV16, HPV18 and HPV45 in cervical cancer. Papillomavirus Res. 2018:5:172-9.

30. Shimamoto K, Saito T, Kitade S, Tomita Y, Nagayama R, Yamaguchi S, et al. A study of treatments and outcomes in elderly women with cervical cancer. Eur J Obstet Gynecol Reprod Biol. 2018;228:174-9.

31. Safaeian M, Sampson JN, Pan Y, Porras C, Kemp TJ, Herrero R, et al. Durability of Protection Afforded by Fewer Doses of the HPV16/18 Vaccine: The CVT Trial. J Natl Cancer Inst. 2018;110(2).

32. Rahma OE, Herrin VE, Ibrahim RA, Toubaji A, Bernstein S, Dakheel O, et al. Pre-immature dendritic cells (PIDC) pulsed with HPV16 E6 or E7 peptide are capable of eliciting specific immune response in patients with advanced cervical cancer. J Transl Med. 2014;12:353.

Ready to submit your research? Choose BMC and benefit from:

- fast, convenient online submission

- thorough peer review by experienced researchers in your field

- rapid publication on acceptance

- support for research data, including large and complex data types

- gold Open Access which fosters wider collaboration and increased citations

- maximum visibility for your research: over $100 \mathrm{M}$ website views per year

At $\mathrm{BMC}$, research is always in progress.

Learn more biomedcentral.com/submissions 